\title{
Variability of diet-tissue isotopic fractionation in estuarine macrobenthos
}

\author{
Hisashi Yokoyama ${ }^{1, *}$, Akio Tamaki ${ }^{2}$, Kazuyuki Harada $^{2}$, Katsumasa Shimoda $^{2}$, \\ Kazuki Koyama ${ }^{2}$, Yuka Ishihi ${ }^{1}$
}

\author{
${ }^{1}$ National Research Institute of Aquaculture, Fisheries Research Agency, Nansei, Mie 516-0193, Japan \\ ${ }^{2}$ Marine Research Institute, Nagasaki University, Taira-Machi 1551-7, Nagasaki 851-2213, Japan
}

\begin{abstract}
Juveniles of bivalves Mactra veneriformis and Ruditapes philippinarum, and ghost shrimps Nihonotrypaea japonica and $N$. harmandi were reared on a microalga of a constant isotopic value to quantify their diet-tissue isotopic fractionation. The weights of the animals increased by $>7$-fold, resulting in isotopic equilibria with their diet. Fractionation for bivalve soft tissues was 0.6 to $0.9 \%$ for carbon and 3.4 to $3.6 \%$ for nitrogen, which fell within the range of the currently accepted fractionation values ( 0 to 1 and 3 to $4 \%$ ). Examinations of acid-treated or untreated whole body, muscle and exoskeleton of the ghost shrimps showed (1) large variations in $\delta^{13} \mathrm{C}$ for untreated exoskeletons, (2) reduced $\delta^{13} \mathrm{C}$ for acid-treated exoskeletons by 3.5 to $6.2 \%$, (3) confined ranges in ${ }^{13} \mathrm{C}$ and ${ }^{15} \mathrm{~N}$ fractionations for muscles (2.0 to 2.2 and 3.6 to $4.0 \%$ ), (4) only slight effects of acid treatment on ${ }^{13} \mathrm{C}$ and ${ }^{15} \mathrm{~N}$ fractionation for muscles $\left(\leq 0.3 \%\right.$ o differences), (5) a significant difference in ${ }^{13} \mathrm{C}$ fractionation for acid-treated whole bodies between $N$. japonica (-0.3\%) and $N$. harmandi $(-1.7 \%$ ), and (6) 2.3 to $3.0 \%$ of ${ }^{15} \mathrm{~N}$ fractionation for whole bodies, which were smaller than for muscles due to negative fractionation for exoskeletons $(-3.0$ to $-1.9 \%$ o). These findings suggest that carbonates in exoskeletons should be removed by acid and that muscle is the most appropriate tissue for isotopic analysis. Although ${ }^{15} \mathrm{~N}$ fractionation for ghost-shrimp muscle was within the above-mentioned accepted range, ${ }^{13} \mathrm{C}$ fractionation was outside this range. The present study highlights that fractionation is speciesand tissue-specific, and that the accepted fractionation values may not be universally applicable.
\end{abstract}

KEY WORDS: Stable isotopes · Trophic enrichment · Feeding experiment · Callianassid shrimp · Bivalve

Resale or republication not permitted without written consent of the publisher

\section{INTRODUCTION}

The stable-carbon and -nitrogen isotope technique has been used increasingly as a tool to analyze food webs in terrestrial and aquatic ecosystems. The analysis is based on a fixed isotopic enrichment between animals and their diets (= trophic shift; hereafter, 'fractionation'); that is, 0 to $1 \%$ for ${ }^{13} \mathrm{C}$ and 3 to $4 \%$ for ${ }^{15} \mathrm{~N}$ (reviewed by Peterson \& Fry 1987). The small ${ }^{13} \mathrm{C}$ enrichment has been utilized for the identification of food sources for animals, whereas the large ${ }^{15} \mathrm{~N}$ enrichment has been utilized to determine their trophic levels. These isotopic fractionation values have gained acceptance by the majority of researchers.
The actual degree of fractionation, however, has been found to be quite variable. DeNiro \& Epstein (1978) investigated the influence of diet on the carbon isotopes in whole bodies in 13 species, mainly composed of terrestrial insects and vertebrates. They reported that the average value of the diet-animal fractionation was $0.8 \%$; however, there was large interspecific variation ranging from -0.6 to $2.7 \%$. Gearing et al. (1984) reviewed laboratory feeding studies and field measurements for the ${ }^{13} \mathrm{C}$ fractionation in animals, and showed values averaging $( \pm \mathrm{SD}) 0.4 \pm 1.4$ and $0.6 \pm 1.6 \%$, respectively. They concluded that the range of the fractionation was too large to generalize with any certainty. As to the nitrogen isotopic fraction- 
ation, Minagawa \& Wada (1984) reported 3.4 $\pm 1.1 \%$ as the mean $( \pm \mathrm{SD}){ }^{15} \mathrm{~N}$ diet-tissue fractionation based on published data and their own field/laboratory studies. However, DeNiro \& Epstein (1981) found a large variation in the fractionation, ranging from -0.1 to $9.2 \%$. Later, Owens (1987) and Vander Zanden \& Rasmussen (2001) also recognized that there were large interand/or intra-specific variations in the diet-animal nitrogen isotopic fractionation. Most recently, McCutchan et al. (2003) reviewed the ${ }^{13} \mathrm{C}$ and ${ }^{15} \mathrm{~N}$ fractionation for terrestrial and aquatic consumers based on data from the literature and their original estimates, and calculated mean $( \pm \mathrm{SD}){ }^{13} \mathrm{C}$ and ${ }^{15} \mathrm{~N}$ fractionation values of $0.5 \pm 1.3$ and $2.3 \pm 1.5 \%$, respectively, for all animals excluding fluid-feeding consumers. In their data shown as histograms (Fig. 1 in McCutchan et al. 2003), only 27 values of 100 measurements for the ${ }^{13} \mathrm{C}$ fractionation fell within the range 0 to $1 \%$ and only 11 values of 73 measurements for the ${ }^{15} \mathrm{~N}$ fractionation fell within the range 3 to $4 \%$. Such large variability in the isotopic fractionation for both carbon and nitrogen will reduce the resolution in studies which use $\delta^{13} \mathrm{C}$ and $\delta^{15} \mathrm{~N}$ for investigating the food-web structure.

The $\delta^{13} \mathrm{C}$ values of shell carbonates of marine and freshwater mollusks are known to primarily reflect the $\delta^{13} \mathrm{C}$ values of $\mathrm{HCO}_{3}{ }^{-}$in water rather than those of the diet (Keith et al. 1964, Frits \& Poplawski 1974). Shells are, therefore, usually excluded prior to $\delta^{13} \mathrm{C}$ measurements for dietary analysis. On the other hand, the source of carbon in the carbonate fraction in exoskeletons of crustaceans has not been determined. In stableisotope studies on crustaceans, either whole bodies or muscles (e.g. Boon et al. 1997, Fry et al. 2003) have been used inconsistently. Furthermore, in some cases, whole-body samples were treated with $\mathrm{HCl}$ to remove carbonates (e.g. Fry \& Arnold 1982, Schlacher \& Wooldridge 1996), while in others, acid treatment was not conducted (e.g. Wada et al. 1987, Frazer et al. 1997). If there are large variations in the diet-tissue isotopic fractionation among different tissues or organs (Tieszen et al. 1983, Hobson \& Clark 1992, Pinnegar \& Polunin 1999) and/or in isotopic compositions, depending on the method of sample preparation (Bunn et al. 1995, Pinnegar \& Polunin 1999), non-standardized methods of the measurement of isotope compositions might lead to different conclusions. Thus, prior to the isotopic analysis of crustaceans, it is important to determine (1) whether the exoskeleton should be included, (2) whether $\mathrm{HCl}$ should be used to treat samples, and (3) which tissue is most suitable for food-source analysis.

When examining the diet-animal fractionation, the following 3 points should be kept in mind. First, isotopic relationships between consumers and their diets should be obtained by controlled feeding experi- ments. Comparison of the isotopic compositions of animals with those of presumed diets only from field surveys may produce ambiguous results in the isotopic fractionation, because animals usually depend on multiple food sources, with each often assuming large temporal and/or spatial variations in isotopic compositions (e.g. Jennings et al. 1997, Cloern et al. 2002). Second, animals reared in the laboratory should be fed a single diet exhibiting a constant isotopic composition with values distinct from possible natural diets. Feeding a compound food containing multiple components with different isotopic compositions (e.g. fish meal, corn and wheat) may potentially produce ambiguous results due to possible differential assimilation rates among these components. Finally, animals should be grown large enough so that the carbon and nitrogen of their initial body tissues are replaced by those of the diet.

Most of the hitherto isotopic fractionation data have been derived from terrestrial insects, mammals and birds, and freshwater animals. Much less information is available on the isotopic fractionation for marine coastal and estuarine animals. Further studies using these animals are necessary to evaluate the generality of the currently accepted fractionation and to describe precise food webs in coastal and estuarine ecosystems. We conducted feeding experiments on 2 bivalves (Veneridae, Mactridae) and 2 ghost shrimps (Decapoda: Thalassinidea: Callianassidae), to determine the carbon and nitrogen isotopic fractionation between diet and animal tissues. Such experiments are a prerequisite for identifying food sources and trophic links in estuarine animals. Small-sized juveniles, shortly after settlement, obtained from intertidal sandflats were used to attain sufficient growth in a relatively short time. During the experiment, they were fed a monospecific algal diet of constant isotopic composition. We also investigated the influence of acid-treatment on tissues and whole bodies of the ghost shrimps to determine whether we should treat samples with $\mathrm{HCl}$ and to determine which tissues were appropriate for isotopic analysis.

\section{MATERIALS AND METHODS}

Feeding experiment on the 2 bivalve species. Juveniles of the bivalves Mactra veneriformis Deshayes in Reeve, 1854 and Ruditapes philippinarum (Adams \& Reeve, 1850), both of which are common in Japanese coastal waters, were collected by hand from an intertidal sandflat at the mouth of Shirakawa River (Shirakawa sandflat at $32^{\circ} 47^{\prime} \mathrm{N}, 130^{\circ} 36^{\prime} \mathrm{E}$ ) in Ariake Sound, western Kyushu on 3 to 4 August 2003. In the laboratory, where room temperature was maintained 
constant at $22^{\circ} \mathrm{C}$, juveniles of each species were placed individually in $300 \mathrm{ml}$ plastic vessels. Each vessel was layered to a depth of $15 \mathrm{~mm}$ with ceramic spheres (diameter $=0.1$ to $0.5 \mathrm{~mm}$, NORRA), filled with seawater and covered with a lid. The seawater was derived from natural seawater that had been pumped through a sand filter to reduce the concentration of organic particles to close to zero (total organic carbon $<0.02 \mathrm{mg} \mathrm{l}^{-1}$, total nitrogen $<0.004 \mathrm{mg} \mathrm{l}^{-1}$, salinity $=$ 32.7 to 33.3). The seawater in the vessels was kept still and replaced every $12 \mathrm{~h}$. A commercial feed liquid (Tasaki Shinju), which contained concentrated living cells of the diatom Chaetoceros gracilis (cell density = $4.8 \times 10^{8} \mathrm{ml}^{-1}$, total organic carbon $=5.3 \mathrm{mg} \mathrm{ml}^{-1}$, total nitrogen $=0.86 \mathrm{mg} \mathrm{ml}^{-1}, \mathrm{C}: \mathrm{N}$ ratio $=6.2$ ), was used as a single food source for the bivalves (Table 1). The $C$. gracilis cells were maintained alive in the refrigerator at $3^{\circ} \mathrm{C}$ during the experiment. Just after the replacement of the rearing seawater, $0.03 \mathrm{ml}$ of the feed liquid was supplied to each vessel. Fourteen $M$. veneriformis with an initial shell length of 2.8 to $3.7 \mathrm{~mm}$ and $16 R$. philippinarum with an initial shell length of 1.9 to $4.5 \mathrm{~mm}$ were reared successfully. The reared $M$. veneriformis were subsampled on Days 21, 24, 30, 36, 42 and 48 for the determination of their isotopic compositions; those of $R$. philippinarum were subsampled after 19, 22, 25, 31, 37, 43 and $49 \mathrm{~d}$. The bivalve growth ratio (GRb), as defined below, was adopted as an index to represent animal growth during the rearing period;
$\mathrm{GRb}=W B f / W B i$, where $W B f$ and $W B i$ are the final and initial dry weights of the whole soft tissues, respectively. The whole soft tissues include all fleshy organs such as the mantle, retractor and adductor muscles, branchia, siphons, labial palp and viscera. WBi was estimated from the shell length at the beginning of the experiment, based on non-linear equations between the dry weight of the whole soft tissues and shell length for each bivalve species (Fig. 1a,b). The specimens used for establishing the equations were collected from the same locality.

In addition to the feeding experiments, starvation experiments were conducted. Between 3 and 5 Mactra veneriformis were subsampled after 18 and $31 \mathrm{~d}$, while Ruditapes philippinarum clams were subsampled after 19 and $32 \mathrm{~d}$. Nutritive conditions of the experimental clams during the experiments were evaluated by an obesity index (\%), defined as (dry weight of the whole soft tissues/dry weight of the whole organism including the shell) $\times 100$.

Feeding experiment on the 2 ghost shrimp species. Juveniles of the ghost shrimp Nihonotrypaea japonica (Ortmann, 1891) were obtained by hand from the intertidal sandflat at the mouth of Shirakawa River on August 27, 2003; those of N. harmandi (Bouvier, 1901) were obtained from an intertidal sandflat on the NW corner of Amakusa-Shimoshima Island (Tomioka Bay sandflat at $32^{\circ} 31^{\prime} \mathrm{N}, 130^{\circ} 02^{\prime} \mathrm{E}$ ), western Kyushu, on August 28, 2003 (see Tamaki et al. 1997). Both species

Table 1. Diet (Chaetoceros gracilis) of the bivalves and ghost shrimps used for the feeding experiment, and growth of these animals during the experiment and in the field

\begin{tabular}{|c|c|c|}
\hline & Bivalve & Ghost shrimp \\
\hline \multicolumn{3}{|l|}{ Diet } \\
\hline Cell density (no. $\mathrm{ml}^{-1}$ ) & $4.8 \times 10^{8}$ & $4.2 \times 10^{8}$ \\
\hline Total organic carbon $\left(\mathrm{mg} \mathrm{ml}^{-1}\right)$ & 5.3 & 2.7 \\
\hline Total nitrogen $\left(\mathrm{mg} \mathrm{ml}^{-1}\right)$ & 0.86 & 0.48 \\
\hline $\mathrm{C}: \mathrm{N}$ ratio & 6.2 & 5.6 \\
\hline Protein ( $\mathrm{g} \mathrm{g}^{-1}$ dry wt) & $0.28^{\mathrm{a}}$ & $0.28^{\mathrm{a}}$ \\
\hline Lipid ( $g g^{-1}$ dry wt) & $0.15^{\mathrm{a}}$ & $0.15^{\mathrm{a}}$ \\
\hline Carbohydrate ( $\mathrm{g} \mathrm{g}^{-1}$ dry wt) & $0.14^{\mathrm{a}}$ & $0.14^{\mathrm{a}}$ \\
\hline Supply rate of diet $\left(\mathrm{ml} \mathrm{d}^{-1}\right)$ & $0.06\left(0.32 \mathrm{mg} \mathrm{C} \mathrm{d}^{-1}\right)$ & $0.5\left(1.35 \mathrm{mg} \mathrm{C} \mathrm{d}^{-1}\right)$ \\
\hline \multicolumn{3}{|l|}{ Growth rate of reared animals } \\
\hline Dry weight of whole soft tissues ${ }^{b, c}$ or & $0.032 \pm 0.025(0.013 \mathrm{mg} \mathrm{C})^{b}$ & $0.081 \pm 0.029(0.029 \mathrm{mg} \mathrm{C})^{\mathrm{d}}$ \\
\hline whole body ${ }^{\mathrm{d}, \mathrm{e}}\left(\right.$ mean $\left.\pm \mathrm{SD} ; \mathrm{mg} \mathrm{d}^{-1}\right)$ & $0.057 \pm 0.040(0.024 \mathrm{mg} \mathrm{C})^{\mathrm{c}}$ & $0.142 \pm 0.049(0.056 \mathrm{mg} \mathrm{C})^{\mathrm{e}}$ \\
\hline Shell length ${ }^{\mathrm{b}, \mathrm{c}}$ or carapace length ${ }^{\mathrm{d}, \mathrm{e}}$ & $0.068 \pm 0.030^{\mathrm{b}}$ & $0.026 \pm 0.008^{\mathrm{d}}$ \\
\hline$\left(\right.$ mean $\left.\pm \mathrm{SD}_{;} \mathrm{mm} \mathrm{d}^{-1}\right)$ & $0.087 \pm 0.038^{\mathrm{c}}$ & $0.032 \pm 0.009^{\mathrm{e}}$ \\
\hline \multicolumn{3}{|l|}{ Growth rate in field populations } \\
\hline Shell length ${ }^{b, c}$ or carapace length $h^{\mathrm{d}, \mathrm{e}}$ & $0.16 \pm 0.04^{\mathrm{b}, \mathrm{f}}$ & $0.018^{\mathrm{d}, \mathrm{h}}$ \\
\hline$\left(\right.$ mean $\left.\pm S D ; \mathrm{mm} \mathrm{d}^{-1}\right)$ & $0.19 \pm 0.12^{\mathrm{c}, \mathrm{g}}$ & $0.014 \pm 0.002^{\mathrm{e}, \mathrm{i}}$ \\
\hline \multicolumn{3}{|c|}{ 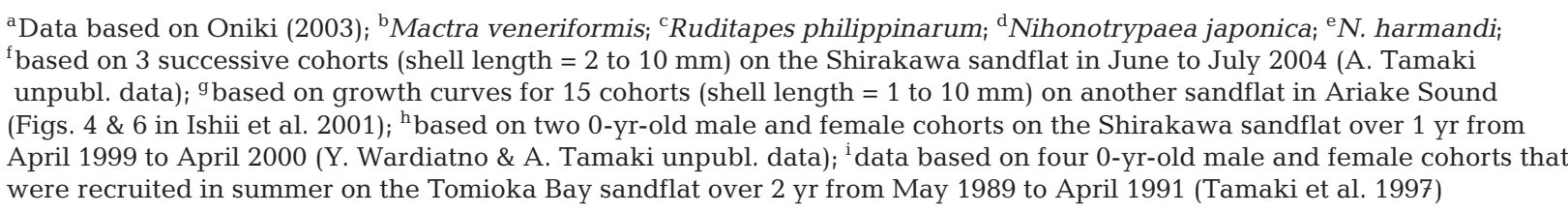 } \\
\hline
\end{tabular}



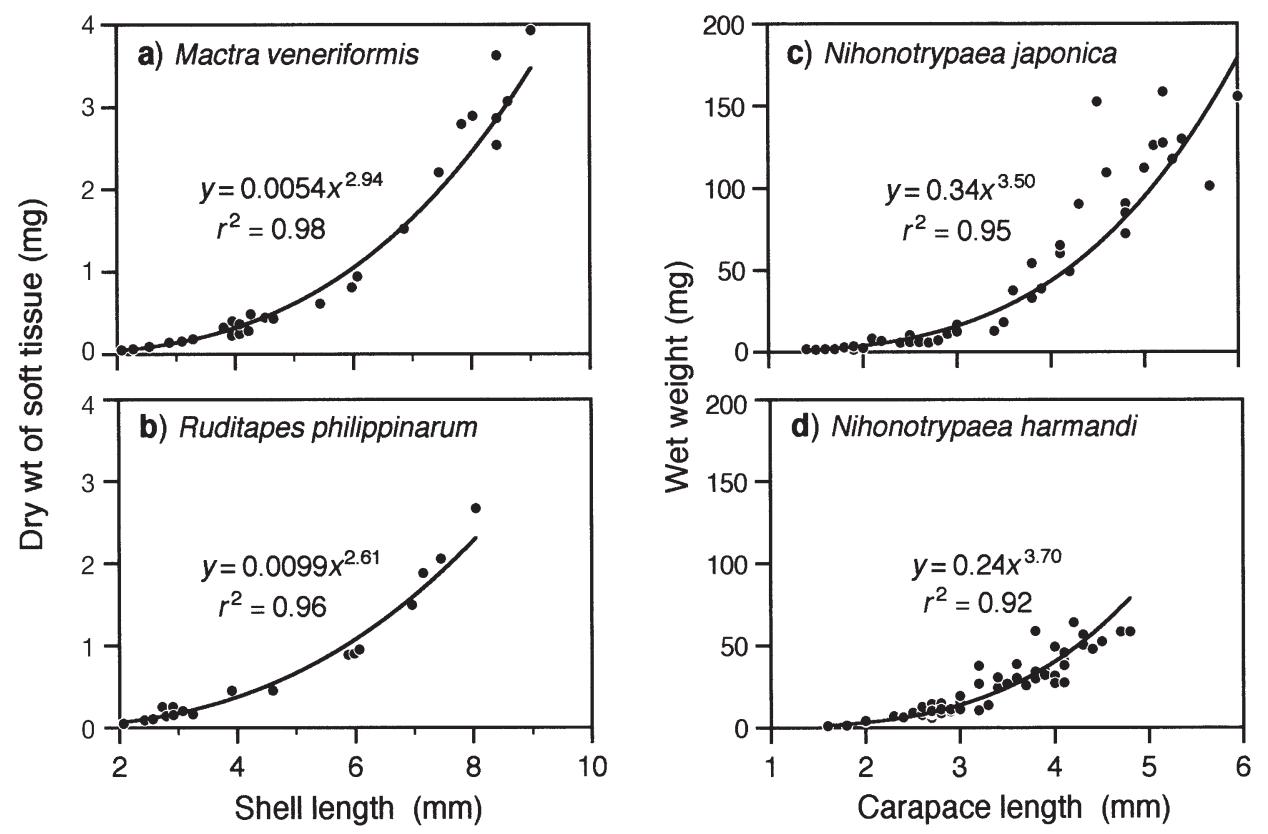

Fig. 1. Allometry of the bivalves and the ghost shrimps

are common in Japanese coastal waters (Tamaki 2003). In the laboratory, each shrimp was placed in a $120 \mathrm{ml}$ plastic vessel (diameter $=45 \mathrm{~mm}$, height $=75 \mathrm{~mm}$ ) filled to a depth of $65 \mathrm{~mm}$ with silica sand (medium

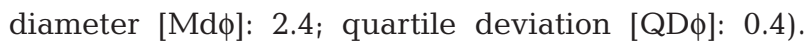
The top of each vessel was covered with a polyethylene net to prevent the shrimps from escaping. For each species, 40 vessels were placed in a container whose height was greater than that of the vessel. Sandfiltered seawater (water temperature $=22.7$ to $28.5^{\circ} \mathrm{C}$ and salinity $=32.4$ to 32.8 during the experiment) with a very low content of biotic particles (total organic carbon $<0.02 \mathrm{mg} \mathrm{l}^{-1}$, total nitrogen $<00.004 \mathrm{mg} \mathrm{l}^{-1}$ ) was supplied at a rate of $1.51 \mathrm{~min}^{-1}$ to each container and overflowed. Thirty-seven $N$. japonica of initial carapace length 1.3 to $2.0 \mathrm{~mm}$ (estimated wet weight of body $=0.4$ to $3.0 \mathrm{mg}$; see below) and $39 \mathrm{~N}$. harmandi of initial carapace length 1.5 to $2.3 \mathrm{~mm}$ (1.0 to $5.7 \mathrm{mg}$ ) were reared successfully. The reared $N$. japonica were subsampled after 30, 35, 40, 45 and $50 \mathrm{~d}$ in order to determine their isotopic compositions; those of $N$. harmandi were subsampled after 30, 33, $35,40,45$ and $50 \mathrm{~d}$. The feed liquid containing Chaetoceros gracilis (cell density $=4.2 \times 10^{8} \mathrm{ml}^{-1}$, total organic carbon $=2.7 \mathrm{mg} \mathrm{ml}^{-1}$, total nitrogen $=0.48 \mathrm{mg}$ $\mathrm{ml}^{-1}, \mathrm{C}: \mathrm{N}$ ratio $=5.6$ ) was used for rearing the ghost shrimps (Table 1). After turning off the seawater supply, $0.25 \mathrm{ml}$ of the feed liquid was supplied to each vessel every $12 \mathrm{~h}$. After feeding, the seawater was kept still for 30 to $60 \mathrm{~min}$. Shrimp growth ratio (GRs), as defined below, was adopted as an index to repre- sent animal growth during the rearing period: GRs = $W S f / W S i$, where $W S f$ and $W S i$ are the final and initial blotted wet weights, respectively. WSi was not measured directly to minimize handling stress associated with blotting; instead, we measured the carapace length under a stereomicroscope and converted it into wet weight using the non-linear equations established from a set of specimens that were not used in the experiment (Fig. 1c,d).

Sample preparation and analysis of isotopic composition. All animal samples were kept frozen until analysis when they were thawed. After the shell and intestine contents of the bivalves were removed under a stereomicroscope, the whole soft tissue of each individual was soaked in $1.2 \mathrm{~N} \mathrm{HCl}$ for 2 to $3 \mathrm{~min}$ to remove any carbonate debris, rinsed with distilled water, dried at $60^{\circ} \mathrm{C}$ for $1 \mathrm{~d}$, and weighed to the nearest $1 \mu \mathrm{g}$. Half the number of the reared ghost shrimp in each species were used for the whole-body measurement. The whole body was dried at $60^{\circ} \mathrm{C}$ after the intestine contents, if present, had been removed, ground to a powder, then divided into 2 subsamples. One subsample was soaked in $1.2 \mathrm{~N} \mathrm{HCl}$ for 4 to $5 \mathrm{~min}$, filtered on a Nuclepore track-etch membrane filter (pore size = $0.2 \mu \mathrm{m})$, rinsed with distilled water, and then dried again (acid-treated). The other subsample received no acid treatment (untreated). The other half sample was prepared for the analysis of muscle and exoskeleton. Muscle from each individual, obtained from abdominal segments and chelipeds, was divided into 2 halves; 1 half was soaked in $1.2 \mathrm{~N} \mathrm{HCl}$ for 2 to $3 \mathrm{~min}$, whereas 
the other half was untreated. Exoskeleton samples were obtained from the carapace, abdomen and chelipeds. Exoskeleton samples from several individuals were treated with $1.2 \mathrm{~N} \mathrm{HCl}$ for 2 to $3 \mathrm{~min}$, and those from the other individuals were untreated. Samples of muscle and exoskeleton were dried at $60^{\circ} \mathrm{C}$. As the individuals of the bivalves and the ghost shrimps for the measurement of initial values were quite small, whole soft tissue or whole body samples were not divided into subsamples for acid treatment and no treatment. Each sample for the measurement of initial values of muscle and exoskeleton of the ghost shrimps was obtained by combining several individuals of minimal body size. Other samples were prepared for individual animals. We omitted lipid removal from the samples to make interspecific comparison with earlier studies (e.g. DeNiro \& Epstein 1978, 1981, Minagawa \& Wada 1984), in which the diet-animal fractionation was determined based on non-defatted samples. The diets for laboratory animals were sampled 3 times during the experiment; Chaetoceros gracilis cells were collected on Whatman GF/F filters, and dried at $60^{\circ} \mathrm{C}$.

The ${ }^{15} \mathrm{~N}$ and ${ }^{13} \mathrm{C}$ composition of the samples was determined using a mass spectrometer (MAT 252, Finnigan MAT) coupled on-line, via a Finnigan ConFlo II interface, with an elemental analyzer (EA 1110, ThermoQuest Italia). The results are expressed in the standard $\delta$ unit notation as $\delta X=\left[\left(R_{\text {samples }} / R_{\text {reference }}\right)-1\right]$ $\times 10^{3}$, where $X$ represents ${ }^{13} \mathrm{C}$ or ${ }^{15} \mathrm{~N}$, and $R$ represents the ${ }^{13} \mathrm{C}:{ }^{12} \mathrm{C}$ or ${ }^{15} \mathrm{~N}:{ }^{14} \mathrm{~N}$ ratios. The standard reference materials were Pee Dee Belemnite standard (PDB) for carbon and atmospheric $\mathrm{N}_{2}$ for nitrogen.

Data analysis. Negative exponential equations of the form $y=a e^{-b x}+c$ were fitted to the experimental data, where $y$ is the $\delta^{13} \mathrm{C}$ or $\delta^{15} \mathrm{~N}$ value of the tissue in question, $x$ is the growth ratio, a and $b$ are constants, and $c$ is an 'asymptotic value' (AV) of the tissue on the diet. The best-fit curves were optimized using the software 'KyPlot' (Kyence). The diet-tissue fractionation (DTF) was calculated as DTF $=\mathrm{AV}-\mathrm{DV}$, where DV is the diet value.

Fry \& Arnold (1982) found that after a 4-fold increase in weight, laboratory-reared shrimps reached an isotopic equilibrium with their new diet. In our experiments, best-fit curves showed that the laboratoryreared bivalves and shrimps with weights $>700 \%$ of the initial weight undoubtedly reached an isotopic equilibrium with their diet (see Figs. 2, 4 \& 5). Here, these animals, which had a growth ratio $>7.0$, are termed as 'diet-equilibrated', and the $\delta^{13} \mathrm{C}$ and $\delta^{15} \mathrm{~N}$ values of these animals are defined as 'final values'. To show the variability in isotopic compositions among these diet-equilibrated animals, the standard deviations from the means were calculated.

\section{RESULTS \\ Diet}

Table 2 shows the isotopic compositions of the diet. The isotopic compositions of the diet used for the bivalves were remarkably constant throughout the experiment. The overall mean $( \pm \mathrm{SD}) \delta^{13} \mathrm{C}$ and $\delta^{15} \mathrm{~N}$ values of this diet were $-14.5 \pm 0.1(\mathrm{n}=12)$ and $-8.9 \pm 0.1 \%$ o $(\mathrm{n}=$ 12), respectively. A different batch of Chaetoceros gracilis was used for the diet of the ghost shrimps. There were significant (Kruskal-Wallis test, $\mathrm{p}<0.05$ ) variations in the mean $\delta^{13} \mathrm{C}$ and $\delta^{15} \mathrm{~N}$ values of the diet among the sampling times. However, the variability was relatively small, as shown by ranges of $0.3 \%$ for $\delta^{13} \mathrm{C}$ and $0.4 \%$ for $\delta^{15} \mathrm{~N}$ during the experimental period. The overall mean $\delta^{13} \mathrm{C}$ and $\delta^{15} \mathrm{~N}$ values of this diet were $-21.6 \pm 0.2(\mathrm{n}=18)$ and $-8.2 \pm 0.2 \%$ o $(\mathrm{n}=18)$, respectively.

\section{Feeding experiments on Mactra veneriformis}

The animals reared on the diet increased by 2.8- to 22 -fold in weight during the experiment. The mean $( \pm \mathrm{SD})$ value of the obesity index calculated for the dietequilibrated clams (i.e. with a growth ratio $>7.0$ ) was $8.4 \pm 1.8 \%(\mathrm{n}=6)$, which was near to the values for clams that were collected from the field and used for the determination of their initial isotopic compositions $(7.2 \pm 1.0 \%, \mathrm{n}=10)$. The changes in the $\delta^{13} \mathrm{C}$ and $\delta^{15} \mathrm{~N}$ values of soft tissues versus growth ratio (i.e. final wt:initial wt) are illustrated in Fig. 2, and the results of the experiment are summarized in Table 3 . The animals, of which initial mean $( \pm \mathrm{SD}) \delta^{13} \mathrm{C}$ and $\delta^{15} \mathrm{~N}$ values for the whole soft tissues were $-17.7 \pm 0.2(n=10)$ and $8.2 \pm 0.1 \%$ o $(n=10)$, respectively, shifted their isotopic compositions rapidly as the growth ratio increased, and the isotopic compositions attained equilibria with their diet. The asymptotic $\delta^{13} \mathrm{C}$ and $\delta^{15} \mathrm{~N}$ values were -13.6 and $-5.3 \%$, respectively, giving a diet-tissue fractionation of 0.9 and $3.6 \%$, respectively.

Table 2. $\delta^{13} \mathrm{C}$ and $\delta^{15} \mathrm{~N}$ of the diet (Chaetoceros gracilis) for reared animals. Numbers in parentheses indicate sample size

\begin{tabular}{|lcll|}
\hline $\begin{array}{l}\text { Reared } \\
\text { animal }\end{array}$ & $\begin{array}{c}\text { Days } \\
\text { elapsed }\end{array}$ & \multicolumn{1}{c|}{$\delta^{13} \mathrm{C} \mathrm{( \% )}$} & $\delta^{15} \mathrm{~N}(\%$ ) \\
\hline Bivalves & 0 & $-14.5 \pm 0.1(4)$ & $-9.0 \pm 0.04(4)$ \\
& 18 & $-14.4 \pm 0.05(4)$ & $-8.9 \pm 0.1(4)$ \\
& 30 & $-14.6 \pm 0.1(4)$ & $-8.9 \pm 0.1(4)$ \\
Ghost & 1 & $-21.6 \pm 0.3(6)$ & $-8.4 \pm 0.1(6)$ \\
shrimps & 21 & $-21.8 \pm 0.1(6)$ & $-8.4 \pm 0.1(6)$ \\
& 48 & $-21.5 \pm 0.04(6)$ & $-8.0 \pm 0.2(6)$ \\
& Mean $\pm \mathrm{SD}$ & $-21.6 \pm 0.2(18)$ & $-8.2 \pm 0.2(18)$ \\
\hline
\end{tabular}


a) Mactra veneriformis
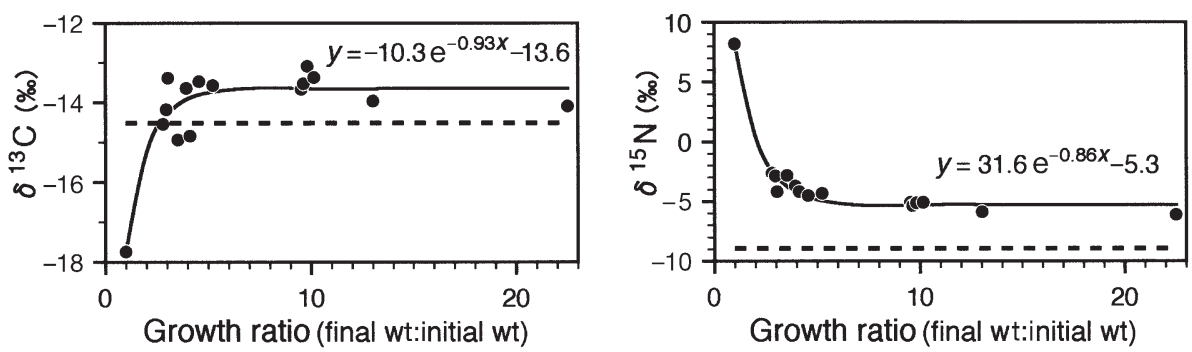

b) Ruditapes philippinarum
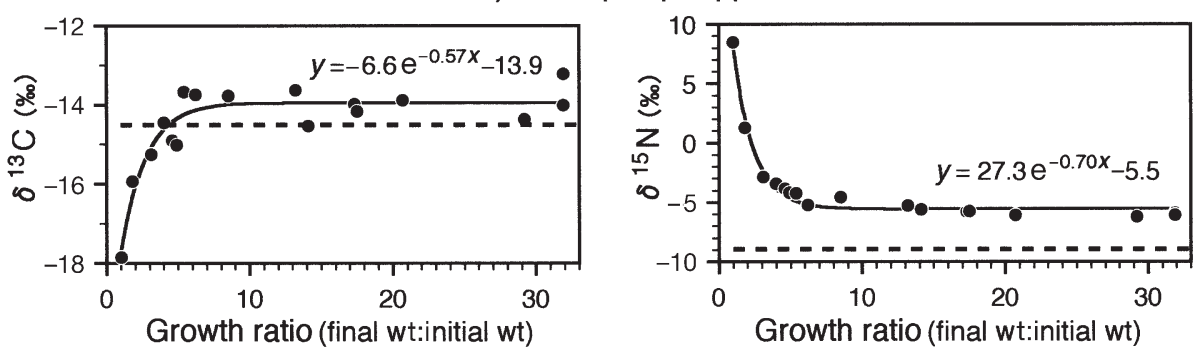

Fig. 2. Mactra veneriformis and Ruditapes philippinarum. $\delta^{13} \mathrm{C}$ (left column) and $\delta^{15} \mathrm{~N}$ (right column) of the 2 bivalve species as a function of the growth ratio. Dashed lines indicate mean $\delta^{13} \mathrm{C}$ or $\delta^{15} \mathrm{~N}$ value of the diet (Table 2). Solid lines and equations are best fit of empirical data

\section{Feeding experiments on Ruditapes philippinarum}

The animals reared on the diet increased by 1.8- to 32 -fold in weight during the experiment. The mean $( \pm \mathrm{SD})$ value of the obesity index calculated for the dietequilibrated clams was $8.5 \pm 1.1 \%(n=9)$, which was significantly greater than the value for the clams collected from the field $(4.0 \pm 0.8 \%, \mathrm{n}=10)$ (MannWhitney $U$-test, $\mathrm{p}<0.001)$. The initial mean $( \pm \mathrm{SD})$ $\delta^{13} \mathrm{C}$ and $\delta^{15} \mathrm{~N}$ values for the whole soft tissue were $-17.8 \pm 0.4(\mathrm{n}=10)$ and $8.5 \pm 0.2 \%$ o $(\mathrm{n}=10)$, respectively (Table 3). The asymptotic $\delta^{13} \mathrm{C}$ and $\delta^{15} \mathrm{~N}$ values of the whole tissues on the diet were -13.9 and $-5.5 \%$, respectively, giving a diet-tissue fractionation of 0.6 and $3.4 \%$, respectively (Fig. 2, Table 3 ).

\section{Starvation experiments on the 2 bivalve species}

Starving the bivalves resulted in a continuous decrease in their wet weight; Mactra veneriformis lost $78 \%$ of their initial weight after $31 \mathrm{~d}$ (initial obesity index $=7.2 \pm 1.0 \%$, final obesity index $=1.6 \pm 0.2 \%$ ); Ruditapes philippinarum lost $60 \%$ after $32 \mathrm{~d}$ (initial obesity index $=4.0 \pm 0.8 \%$, final obesity index $=1.6 \pm$ $0.4 \%$ ) (Fig. 3). In both bivalves, there was no significant change in the $\delta^{13} \mathrm{C}$ values during the experiment, whereas significant (Kruskal-Wallis test, p < 0.005) increases in the $\delta^{15} \mathrm{~N}$ values with time were detected. The $\delta^{15} \mathrm{~N}$ values for $M$. veneriformis increased from 8.2 $\pm 0.1(\mathrm{n}=10)$ to $9.5 \pm 0.2 \%(\mathrm{n}=5)$ at the end of the experiment, while those for $R$. philippinarum increased from $8.5 \pm 0.2(\mathrm{n}=10)$ to $9.1 \pm 0.1 \%(\mathrm{n}=4)$.

\section{Feeding experiments on Nihonotrypaea japonica}

The initial $\delta^{13} \mathrm{C}$ values ranged from $-17.4 \%$ for the whole body with acid treatment to $-11.7 \%$ for the untreated exoskeleton, and the initial $\delta^{15} \mathrm{~N}$ values ranged from $5.9 \%$ for the acid-treated exoskeleton to $11.6 \%$ for untreated muscle (Table 3 ). The animals increased by 4.4 - to 52 -fold in weight during the experiment, and the $\delta^{13} \mathrm{C}$ and $\delta^{15} \mathrm{~N}$ values of their tissues attained equilibria with the diet (Fig. 4). The asymptotic $\delta^{13} \mathrm{C}$ value of the untreated whole body was $-20.0 \%$, giving a diet-tissue fractionation of $1.6 \%$, whereas the whole body with acid treatment had an asymptotic $\delta^{13} \mathrm{C}$ value of $-21.9 \%$, giving a diet-tissue isotopic fractionation of $-0.3 \%$. A comparison between the final $\delta^{13} \mathrm{C}$ values of the untreated and acid-treated whole bodies $(-19.9 \pm 1.0$ vs. $-21.9 \pm 0.5 \%)$ showed that the acid treatment resulted in a significant (paired $t$-test, $\mathrm{p}<0.001)$ reduction in $\delta^{13} \mathrm{C}$, which approximated $2.0 \%$. The untreated and acid-treated muscles of the diet-equilibrated shrimps had nearly the same asymptotic $\delta^{13} \mathrm{C}$ value $(-19.5$ and $-19.6 \%$, respectively), giving diet-tissue fractionations of 2.1 and $2.0 \%$, respectively. The $\delta^{13} \mathrm{C}$ values of the untreated exoskeleton of the diet-equilibrated shrimps showed 


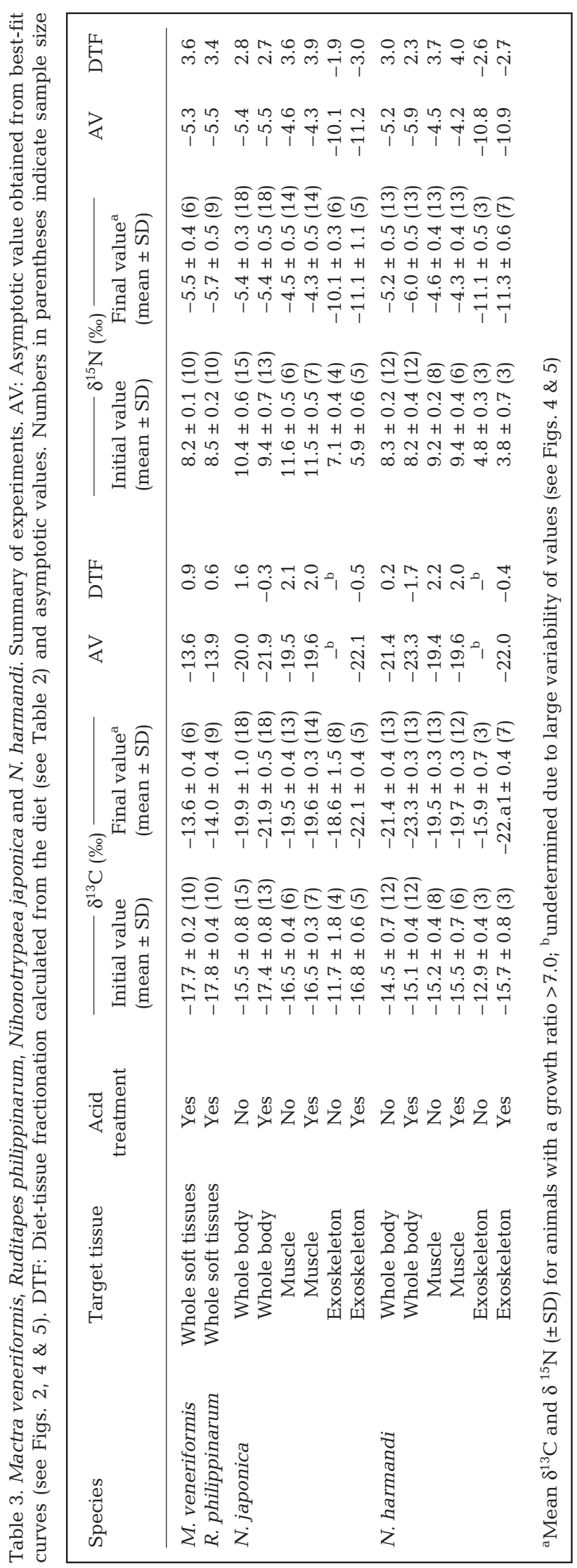

a) Mactra veneriformis

b) Ruditapes philippinarum
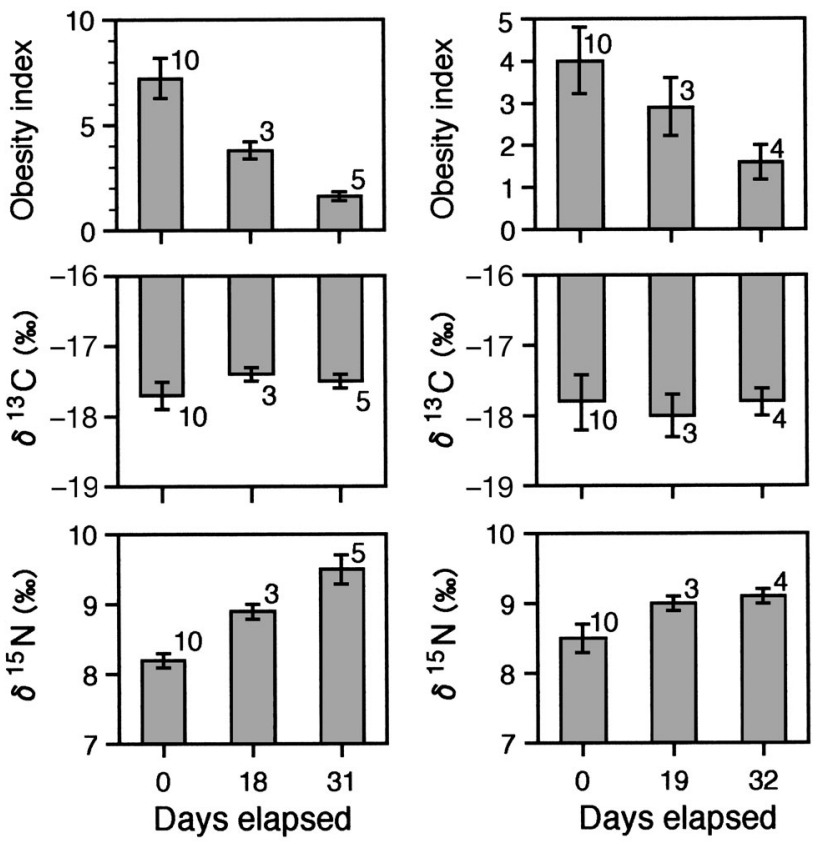

Fig. 3. (a) Mactra veneriformis and (b) Ruditapes philippinarum. Obesity index (upper panels), $\delta^{13} \mathrm{C}$ (middle panels), and $\delta^{15} \mathrm{~N}$ (lower panels) during starvation experiment. See text for the definition of obesity index. Bars represent standard deviation. Sample size (n) is given above or below each bar

an overall enrichment $(-18.6 \pm 1.5 \%$, $\mathrm{n}=8)$, but these values were so variable that the fractionation was indeterminable. The $\delta^{13} \mathrm{C}$ values of the acid-treated exoskeleton $(-22.1 \pm 0.4 \%, \mathrm{n}=5)$ were $3.5 \%$ lower and less variable than those for the untreated exoskeleton. The diet-tissue carbon isotopic fractionation of the acid-treated exoskeleton was $-0.5 \%$.

The untreated and acid-treated whole bodies had similar asymptotic $\delta^{15} \mathrm{~N}$ values $(-5.4$ and $-5.5 \%$, respectively), giving diet-tissue fractionations of 2.8 and $2.7 \%$, respectively (right column in Fig. 4, Table 3 ). Acid treatment had no significant (paired $t$-test, $\mathrm{p}>0.05$ ) effect on the $\delta^{15} \mathrm{~N}$ value of the whole body. Muscle of the dietequilibrated shrimps had asymptotic $\delta^{15} \mathrm{~N}$ values of $-4.6 \%$ for untreated samples and $-4.3 \%$ for acid-treated samples, giving fractionations of 3.6 and $3.9 \%$, respectively. Although acid treatment resulted in a small enrichment in muscle ${ }^{15} \mathrm{~N}$ of $0.2 \%$ (final value for the untreated and acid-treated muscles $=-4.5 \pm 0.5$ and $-4.3 \pm$ $0.5 \%$, respectively), it was significant (paired $t$-test, $\mathrm{p}<0.01$ ). The untreated and acid-treated exoskeletons had asymptotic $\delta^{15} \mathrm{~N}$ values of -10.1 and $-11.2 \%$, respectively, giving negative fractionations of -1.9 and $-3.0 \%$, respectively. A comparison between the final $\delta^{15} \mathrm{~N}$ values for the untreated and acid-treated exoskeletons showed that there was no significant (MannWhitney $U$-test, $\mathrm{p}>0.05$ ) difference between them. 

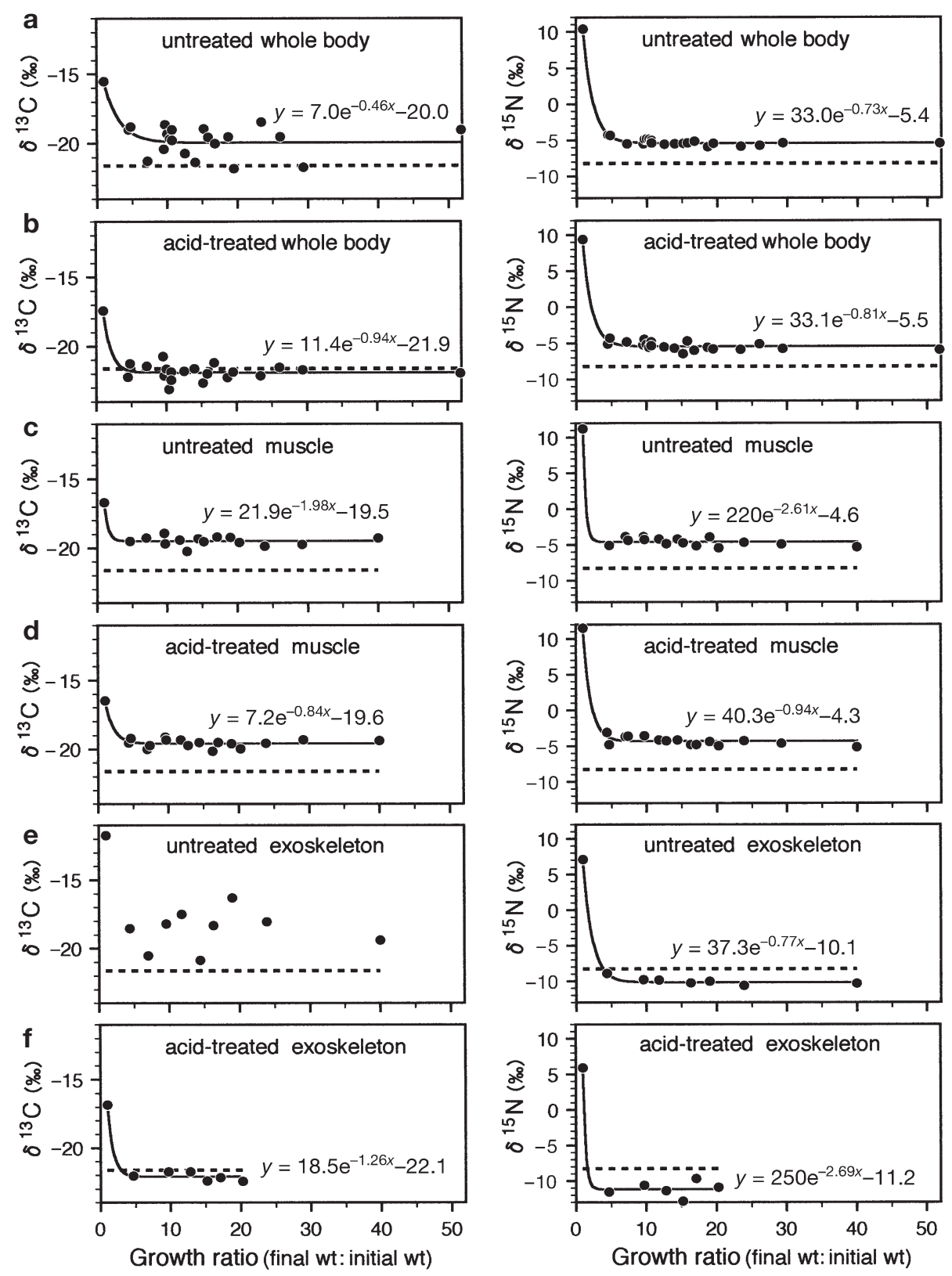

Fig. 4. Nihonotrypaea japonica. $\delta^{13} \mathrm{C}$ (left column) and $\delta^{15} \mathrm{~N}$ (right column) of (a) untreated whole body, (b) acid-treated whole body, (c) untreated muscle, (d) acid-treated muscle, (e) untreated exoskeleton, and (f) acid-treated exoskeleton, as a function of growth ratio. Dashed lines indicate mean $\delta^{13} \mathrm{C}$ or $\delta^{15} \mathrm{~N}$ value of the diet. Solid lines and equations are best fit of empirical data

\section{Feeding experiments on Nihonotrypaea harmandi}

The animals increased by 3.3- to 49 -fold in weight during the experiment. The initial mean $\delta^{13} \mathrm{C}$ and $\delta^{15} \mathrm{~N}$ values ranged from $-15.7 \%$ for the acid-treated exoskeleton to $-12.9 \%$ for the untreated exoskeleton, and from $3.8 \%$ for the acid-treated exoskeleton to $9.4 \%$ for the acid-treated muscle, respectively (Table 3). The $\delta^{13} \mathrm{C}$ values of tissues were plotted against the growth ratio (left column in Fig. 5). The asymptotic $\delta^{13} \mathrm{C}$ value of the untreated whole body was $-21.4 \%$, giving a diet-tissue fractionation of $0.2 \%$, whereas the acid-treated whole body had an asymptotic $\delta^{13} \mathrm{C}$ value of $-23.3 \%$, giving a diet-tissue fractionation of $-1.7 \%$. The acid treatment had a significant (paired $t$-test, $\mathrm{p}<0.001$ ) effect on the whole body, resulting in a $1.9 \%$ reduction in the $\delta^{13} \mathrm{C}$ value. The diet-equilibrated shrimps had asymptotic values of $-19.4 \%$ for untreated muscle (fractionation $=2.2 \%$ ), and $-19.6 \%$ for acid-treated muscle (fractionation = 

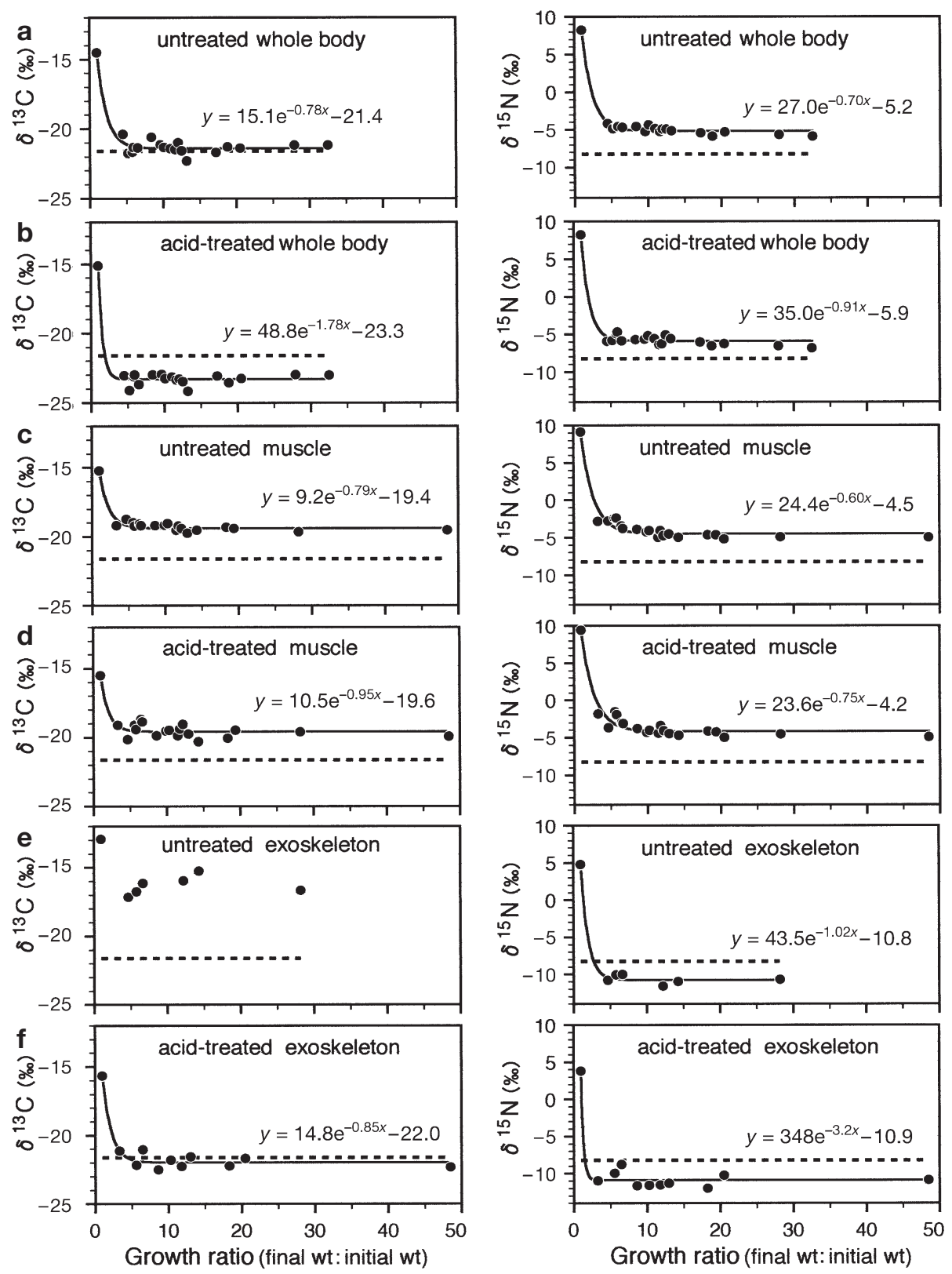

Fig. 5. Nihonotrypaea harmandi. $\delta^{13} \mathrm{C}$ (left column) and $\delta^{15} \mathrm{~N}$ (right column) of (a) untreated whole body, (b) acid-treated whole body, (c) untreated muscle, (d) acid-treated muscle, (e) untreated exoskeleton, and (f) acid-treated exoskeleton, as a function of growth ratio. Dashed lines indicate mean $\delta^{13} \mathrm{C}$ or $\delta^{15} \mathrm{~N}$ value of the diet. Solid lines and equations are best fit of empirical data

$2.0 \%$ ). The acid treatment of muscle resulted in a slight $(0.2 \%$ ) but significant (paired $t$-test, $\mathrm{p}<0.05)$ reduction in the $\delta^{13} \mathrm{C}$ value. The untreated exoskeleton of the diet-equilibrated shrimps had a final $\delta^{13} \mathrm{C}$ value of $-15.9 \pm 0.7 \%$ o $(n=3)$, but the diet-tissue fractionation was indeterminable due to the large variability in the values. The acid-treated exoskeleton showed significantly different (Mann-Whitney $U$-test, $\mathrm{p}<0.001$ ) and less variable values $(-22.1 \pm 0.4 \%$, $\mathrm{n}=7)$. Thus, acid treatment resulted in a $6.2 \%$ reduction in the $\delta^{13} \mathrm{C}$ of exoskeleton. The diet-tissue carbon fractionation for the acid-treated exoskeleton was $-0.4 \%$.

The asymptotic $\delta^{15} \mathrm{~N}$ value of the untreated whole body was $-5.2 \%$, giving a diet-tissue fractionation of $3.0 \%$, whereas the acid-treated whole body had an equilibrium value of $-5.9 \%$, giving a fractionation of $2.3 \%$ (right column in Fig. 5, Table 3). A comparison between the final $\delta^{15} \mathrm{~N}$ values of the untreated and acid-treated whole bodies ( $-5.2 \pm 0.5$ vs. $-6.0 \pm 0.5 \%$ ) showed that acid treatment led to a significant (paired 
$t$-test, $\mathrm{p}<0.01)$ reduction in $\delta^{15} \mathrm{~N}$. The diet-equilibrated shrimps had an asymptotic $\delta^{15} \mathrm{~N}$ value of $-4.5 \%$ for untreated muscle (fractionation $=3.7 \%$ ), and $-4.2 \%$ o for acid-treated muscle (fractionation $=4.0 \%$ ). The effect of acid treatment on the $\delta^{15} \mathrm{~N}$ of muscle was significant (paired $t$-test, $\mathrm{p}<0.01$ ). The untreated and acid-treated exoskeletons of the diet-equilibrated shrimps had similar asymptotic $\delta^{15} \mathrm{~N}$ values of -10.8 and $-10.9 \%$, respectively, giving negative fractionations of -2.6 and $-2.7 \%$, respectively.

\section{DISCUSSION}

\section{Factors for the successful feeding experiment}

The 2 bivalve species Mactra veneriformis and Ruditapes philippinarum, and 2 ghost shrimp species $\mathrm{Ni}$ honotrypaea japonica and $N$. harmandi are commonly found on intertidal sandflats in Japan. They were reared on a monospecific microalga with little fluctuation in isotopic compositions, exhibiting values distinct from those of possible natural diets, in order to quantify their diet-tissue isotopic fractionation. The weights of these juveniles increased by 7 - to 52 -fold within 30 to $50 \mathrm{~d}$ and the juveniles undoubtedly reached isotopic equilibrium with their diet. Fry \& Arnold (1982) found that after a 4-fold increase in weight, shrimp approached isotopic equilibrium with their diet. Thus, we could successfully quantify the diet-tissue isotopic fractionation. The success of the experiments depended on the collection of the earliest-stage juveniles (smallest sizes), resulting in a rapid increase in their weight over a short time interval. The success also depended on the selection of a commercial feed liquid, which is specifically produced for culturing larvae and juveniles of bivalves, shrimps and sea cucumbers by Tasaki Shinju (Oniki 2003). The diet contained concentrated Chaetoceros gracilis cells $\left(4.2 \times 10^{8}\right.$ to $\left.4.8 \times 10^{8} \mathrm{ml}^{-1}\right)$ with high contents of proteins $\left(0.28 \mathrm{~g} \mathrm{~g} \mathrm{~g}^{-1}\right.$ dry wt) and lipids ( $0.15 \mathrm{~g} \mathrm{~g} \mathrm{~g}^{-1} \mathrm{dry} \mathrm{wt}$ ) (Table 1$)$. We supplied $0.06 \mathrm{ml}$ $(0.32 \mathrm{mg} \mathrm{C})$ and $0.5 \mathrm{ml}(1.35 \mathrm{mg} \mathrm{C}) \mathrm{d}^{-1}$ of the diet for the bivalves and ghost shrimps, respectively. The growth rates (mean $\pm \mathrm{SD}$ ) of these animals were $0.032 \pm$ $0.025 \mathrm{mg} \mathrm{dry} \mathrm{wt} \mathrm{d}^{-1}$ (= $0.013 \mathrm{mg} \mathrm{C}$ [mean] $=4 \%$ of supplied carbon in the diet) for $M$. veneriformis, $0.057 \pm$ $0.040 \mathrm{mg} \mathrm{d}^{-1}(=0.024 \mathrm{mg} \mathrm{C}=8 \%)$ for $R$. philippinarum, $0.081 \pm 0.029 \mathrm{mg} \mathrm{d}^{-1}(=0.029 \mathrm{mg} \mathrm{C}=2 \%)$ for $N$. japonica, and $0.142 \pm 0.049 \mathrm{mg} \mathrm{d}^{-1}(=0.056 \mathrm{mg} \mathrm{C}=4 \%)$ for $N$. harmandi. The growth rate in carapace length of the ghost shrimps in the laboratory exceeded that in the field (i.e. 0.026 vs. $0.018 \mathrm{~mm} \mathrm{~d}^{-1}$ for $N$. japonica, Y. Wardiatno \& A. Tamaki unpubl. data; 0.032 vs. $0.014 \mathrm{~mm}$ $\mathrm{d}^{-1}$ for $N$. harmandi, Tamaki et al. 1997), whereas the growth rate in shell length of the bivalves in the labora- tory was inferior to that in the field populations (i.e. 0.068 vs. $0.16 \mathrm{~mm} \mathrm{~d}^{-1}$ for $M$. veneriformis, A. Tamaki unpubl. data; 0.087 vs. $0.19 \mathrm{~mm} \mathrm{~d}^{-1}$ for $R$. philippinarum, Ishii et al. 2001). However, the obesity index showed that the 2 bivalves were well fattened up at the termination of the feeding experiment in comparison with clams in the field (i.e. $8.4 \%$ in the laboratory vs. $7.2 \%$ in the field for $M$. veneriformis, 8.5 vs. $4.0 \%$ for $R$. philippinarum). Overall, the experiment was a success due to the nutritious diet and effective feeding.

\section{Selection of target tissues for the isotopic analysis in crustaceans}

From this study, we first discuss what effect might occur in the acid treatment of samples. In sample preparation, we usually exclude shells for mollusks, because the shell contains carbonate derived from the dissolved inorganic carbon, not from the diet (Keith et al. 1964, Frits \& Poplawski 1974). It was assumed that crustaceans also deposit $\mathrm{CaCO}_{3}$ in their exoskeletons by using external $\mathrm{HCO}_{3}{ }^{-}$derived from seawater (Roer \& Dillaman 1993). Based on this assumption, removing or acid-treating of exoskeletons is conducted prior to crustacean isotopic analysis (Schlacher \& Wooldridge 1996, Boon et al. 1997, Fantle et al. 1999, Fry et al. 2003). However, the source of carbon in the carbonate fraction in crustacean exoskeletons has not been thoroughly established. Bosley \& Wainright (1999) did not observe significant effects on the $\delta^{13} \mathrm{C}$ values of tails (including exoskeleton) of the sand shrimp Crangon septemspinosa after treatment with $\mathrm{HCl}$ during tissuesample processing. In contrast, we found a conspicuous ${ }^{13} \mathrm{C}$ reduction by acid treatment of the exoskeleton and large variations in $\delta^{13} \mathrm{C}$ values of untreated exoskeletons. Our findings show that the carbonate fraction in exoskeleton exhibits $\delta^{13} \mathrm{C}$ values distinct from those of the diet and thus, the $\delta^{13} \mathrm{C}$ values will vary in the process of calcification of the exoskeleton. Our results, therefore, support the hypothesis that carbon used for calcification in the exoskeleton comes from seawater-derived carbonates. If this is true, carbonates in the exoskeleton should be removed from tissues containing exoskeleton by acid treatment. Acid treatment also had significant effects on the isotopic composition of muscle. However, its effects were small (i.e. a 0.1 to $0.2 \%$ decrease in $\delta^{13} \mathrm{C}$ and a 0.2 to $0.3 \%$ increase in $\delta^{15} \mathrm{~N}$ for both species). This result is inconsistent with the findings of Bunn et al. (1995), who reported a conspicuous increase in the $\delta^{15} \mathrm{~N}$ value $(\sim 3 \%)$ for muscle samples of Metapenaeus spp.

As differential isotopic fractionation usually occurs among different organs, tissues and biochemical compounds (Tieszen et al. 1983, Hobson \& Clark 1992, Pin- 
negar \& Polunin 1999, Jim et al. 2004), a question arises as to how much each of the typical target tissues fractionates dietary carbon and nitrogen and which tissues should be sampled for an accurate dietary reconstruction. Our results show that exoskeletons of the ghost shrimps had negative ${ }^{15} \mathrm{~N}$ fractionation, ranging from -3.0 to $-1.9 \%$. The reduction in ${ }^{15} \mathrm{~N}$ might be due to the effect of chitin, which is a major component of crustacean exoskeletons. It has been reported that nitrogen in chitin is depleted by 6.6 to $9.5 \%$ relative to their diet (DeNiro \& Epstein 1981, Schimmelmann $\&$ DeNiro 1986). The lower ${ }^{15} \mathrm{~N}$ fractionation by the whole body (2.3 to $3.0 \%$ ) as compared with the fractionation of muscle (3.6 to $4.0 \%$ o) in our experiments might also be due to the effect of chitin in the exoskeleton. The present results indicate that the diet-tissue nitrogen fractionation for crustaceans is potentially variable, depending on the inclusion or exclusion of exoskeleton in the analysis.

The carbon isotopic fractionation for the untreated and acid-treated whole bodies was found to be significantly different between the 2 ghost shrimps (MannWhitney $U$-test, $\mathrm{p}<0.01)$. The acid-treated and untreated whole bodies of Nihonotrypaea japonica had a greater enrichment over $N$. harmandi by $1.4 \%$, although both species were reared on the same diet and under the same conditions. This is inconsistent with the finding of DeNiro \& Epstein (1978), in that the ${ }^{13} \mathrm{C}$ fractionation was found to be similar for different species reared on the same diet. The cause of this difference is unknown at present. However, considering that lipids usually possess lower $\delta^{13} \mathrm{C}$ values than other biochemical fractions (DeNiro \& Epstein 1978, Tieszen et al. 1983) and that shrimps have a hepatopancreas containing large quantities of lipids exhibiting low $\delta^{13} \mathrm{C}$ values (Fry et al. 2003), the discrepancy in the $\delta^{13} \mathrm{C}$ values between the 2 species of Nihonotrypaea may reflect differences in their biochemical composition.

In contrast to the whole-body data, there was no difference in the ${ }^{13} \mathrm{C}$ fractionation in muscle between the 2 species. This finding suggests that the analysis of muscle provides a better measure of diet-tissue fractionation than whole-body analysis. Acid treatment on muscle samples would be unnecessary, unless debris of exoskeletons or any other inorganic carbonates are included in the samples.

\section{General interspecific comparison of the diet-tissue fractionation}

Table 4 summarizes the diet-animal isotopic fractionation determined for coastal and estuarine animals. Considerable variation exists in the fractionation be- tween species and between conspecific individuals fed different diets (Fig. 6). As to the nitrogen fractionation, there is a large variation ranging from -0.7 to $5.8 \%$, and only 3 values measured for an amphipod fed Ulva detritus (2.7\%o, Macko et al. 1982), a prawn fed zooplankton (2.7\%o, Dittel et al. 1997) and a crab fed meiobenthos (3.1\%, Fantle et al. 1999) are within the range of or close to the currently accepted trophic fractionation of 3 to $4 \%$. Macko et al. (1982) reported negative fractionation for 2 amphipods reared on macroalgae. In contrast, a large ${ }^{15} \mathrm{~N}$ enrichment showing fractionation of $>5 \%$ o was found for phytoplanktongrazing copepods (Checkley \& Entzeroth 1985) and zooplanktivorous fish (Gaston \& Suthers 2004). In the present study, the nitrogen fractionations for the 2 bivalves (3.4 to $3.6 \%$ ) and muscle of the 2 ghost shrimps (3.6 to $4.0 \%$ ) are within the currently accepted range.

Fantle et al. (1999) found that nitrogen isotopic fractionation between the blue crab and its diet was dependent on the protein content (generally expressed as the C:N ratio) of the diet. Adams \& Sterner (2000) also found a similar phenomenon in the relationship between the $\delta^{15} \mathrm{~N}$ values of the cladoceran Daphnia magna and the C:N ratio of its diet. These 2 reports suggest that minimum fractionation in ${ }^{15} \mathrm{~N}$ occurrs between animals and their diets with low $\mathrm{C}: \mathrm{N}$ ratios $(<6)$ and that the fractionation increases with the C:N ratio of the diet. Although our experiments provided no information on the effects of food quality on the fractionation, relatively high values of ${ }^{15} \mathrm{~N}$ enrichment (3.4 to $4.0 \%$ ) in bivalve soft tissues and ghost-shrimp muscle were recorded in spite of the use of a proteinrich algal food (protein content $=0.28 \mathrm{~g} \mathrm{~g}^{-1}$ dry wt) with relatively low $\mathrm{C}: \mathrm{N}$ ratios (5.6 to 6.2 ) (Table 1 ).
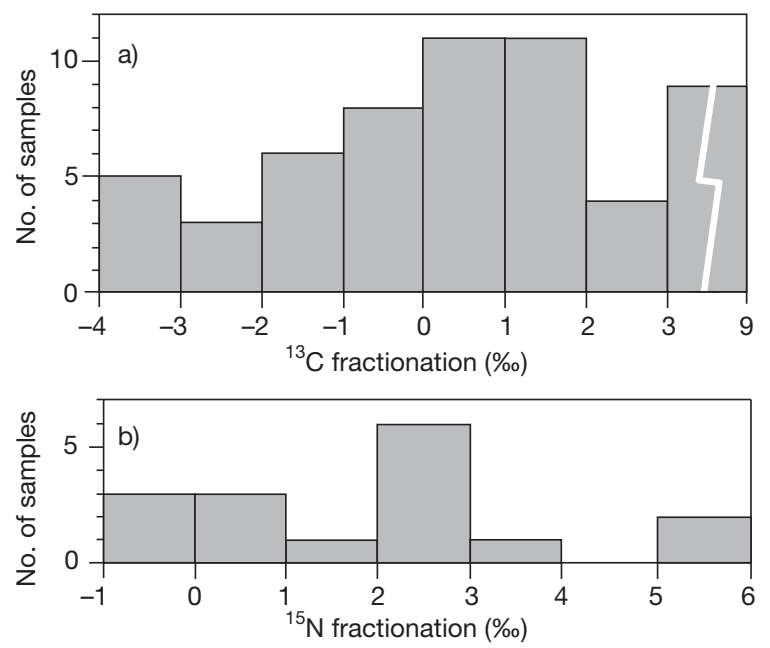

Fig. 6. Frequency distributions of the (a) ${ }^{13} \mathrm{C}$ and (b) ${ }^{15} \mathrm{~N}$ diettissue fractionation for coastal and estuarine animals based on a literature survey (see Table 4) 


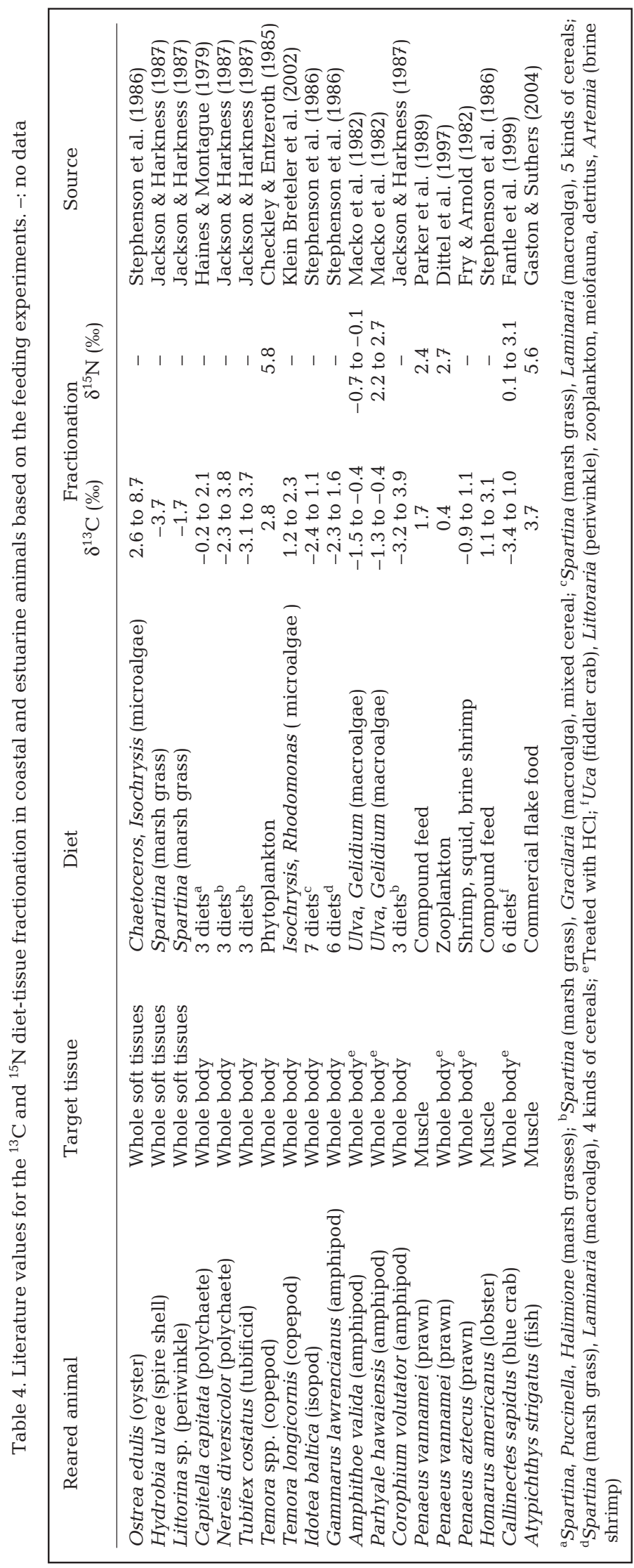

Excretion of isotopically light ammonium is thought to be one of the factors underlying isotopic fractionation of nitrogen in animal tissues (Minagawa \& Wada 1984, Checkley \& Miller 1989, Altabet \& Small 1990). The increases in the $\delta^{15} \mathrm{~N}$ values in Mactra veneriformis (by $1.3 \%$ ) and in Ruditapes philippinarum (by $0.6 \%$ ) during starvation in our experiments reflect the catabolization of their body nitrogen. The diet-tissue fractionation of nitrogen, however, showed much larger values (3.4 to $3.6 \%$ o), suggesting that isotopic fractionation occurs primarily during the production of new tissues through anabolic processes.

Previous feeding experimental studies on coastal and estuarine animals have also indicated that the diet-tissue carbon isotopic fractionation is quite variable, ranging from -3.7 to $8.7 \%$ with a mean $( \pm \mathrm{SD})$ of $0.6 \pm 2.5 \%$ o (Table 4$)$. In addition, several studies have demonstrated that isotopic fractionation can vary depending on food quality (Haines \& Montague 1979, Fry \& Arnold 1982, Stephenson et al. 1986, Jackson \& Harkness 1987, Fantle et al. 1999, Klein Breteler 2002, McCutchan et al. 2003). In the source data for Table 4, only 11 values of the 57 measurements for $\delta^{13} \mathrm{C}$ fell within the range of the currently accepted fractionation (0 to $1 \%$ ), while nearly half (27 measurements) were either less than $-1 \%$ or more than $2 \%$ (Fig. 6a). Our results indicate that the fractionations for the 2 bivalves ( 0.6 to $0.9 \%$ ) were in agreement with the currently accepted fractionation, whereas those for the ghost shrimp muscle (2.0 to $2.2 \%$ ) were outside the range of the currently accepted fractionation values. Parker et al. (1989) found a $1.7 \%$ enrichment in ${ }^{13} \mathrm{C}$ of prawn muscle, which is similar to our results, suggesting that muscle tissues of crustaceans may have larger fractionation than the currently accepted fractionation. The difference found in the fractionation between the ghost shrimps and the bivalves is probably due to the choice of tissue analyzed (i.e. muscle for the former and whole soft tissues for the latter), because $\delta^{13} \mathrm{C}$ is usually lower for animals analyzed whole than for animals analyzed using muscle tissue, which is low in lipid (McCutchan et al. 2003).

\section{CONCLUSION}

We successfully quantified the diet-tissue isotopic fractionation for 2 bivalve species and 2 ghost shrimp species, which were reared on a microalgal diet in the laboratory. The success of the experiments depends on (1) the collection of the earlieststage juveniles with smallest sizes, resulting in 
rapid increase in their weight in a short time interval and (2) the selection of a nutritional monospecific diet with little fluctuation in isotopic composition, exhibiting values distinct from those of possible natural diets.

To determine which tissues of crustaceans are appropriate for isotopic analysis, the ${ }^{13} \mathrm{C}$ and ${ }^{15} \mathrm{~N}$ fractionation for acid-treated or untreated tissues (whole body, muscle and exoskeleton) of the ghost shrimps was examined. The results suggest that carbonates in the exoskeleton should be removed by acid treatment and that muscle is the most appropriate tissue for isotopic analysis of decapod crustaceans.

The diet-tissue fractionation for acid-treated whole soft tissues of the bivalves was 0.6 to $0.9 \%$ for carbon and 3.4 to $3.6 \%$ for nitrogen, respectively, which are within the range of the currently accepted fractionation for various kinds of animals (i.e. 0 to $1 \%$ for carbon and 3 to $4 \%$ for nitrogen). The ${ }^{15} \mathrm{~N}$ fractionation for muscle of the ghost shrimps (3.6 to $4.0 \%$ ) was also within the range, whereas their ${ }^{13} \mathrm{C}$ fractionation (2.0 to $2.2 \%$ ) was outside this range.

Stable isotope studies have contributed to the elucidation of numerous food web structures in different environments. Most of these studies have used $\delta^{13} \mathrm{C}$ and $\delta^{15} \mathrm{~N}$ as natural tracers under the assumption that all consumers have a similar and fixed isotopic enrichment versus their diet, as given in some influential review papers (e.g. Minagawa \& Wada 1984, Peterson \& Fry 1987). However, our results indicate that the fractionation is species- and tissue-specific and that the classical diet-tissue carbon isotopic fractionation is not applicable to all animals and/or ecological systems. More laboratory-determined, species- and tissuespecific fractionation for estuarine animals, especially for crustaceans, will be necessary to be able to fully interpret stable isotope data obtained from the field.

Acknowledgements. We wish to thank Y. Nakamura and I. Kawahara for their valuable suggestions concerning the rearing method of juvenile bivalves. This research was funded by the Japan Society for the Promotion of Science (JSPS) Grantin Aid for Scientific Research 13854006 and 15570018.

\section{LITERATURE CITED}

Adams TS, Sterner RW (2000) The effect of dietary nitrogen content on trophic level ${ }^{15} \mathrm{~N}$ enrichment. Limnol Oceanogr 45:601-607

Altabet MA, Small LF (1990) Nitrogen isotopic ratios in fecal pellets produced by marine zooplankton. Geochim Cosmochim Acta 54:155-163

Boon PI, Bird FL, Bunn SE (1997) Diet of the intertidal callianassid shrimps Biffarius arenosus and Trypea australiensis (Decapoda: Thalassinidea) in Western Port (southern Australia), determined with multiple stableisotope analyses. Mar Freshw Res 48:503-511

Bosley KL, Wainright SC (1999) Effects of preservatives and acidification on the stable isotope ratios $\left({ }^{15} \mathrm{~N}:{ }^{14} \mathrm{~N},{ }^{13} \mathrm{C}:{ }^{12} \mathrm{C}\right)$ of two species of marine animals. Can J Fish Aquat Sci 56: 2181-2185

Bunn SE, Loneragan NR, Kempster MA (1995) Effects of acid washing on stable isotope ratios of $\mathrm{C}$ and $\mathrm{N}$ in penaeid shrimp and seagrass: implications for food-web studies using multiple stable isotopes. Limnol Oceanogr 40: $622-625$

Checkley DM Jr, Entzeroth LC (1985) Elemental and isotopic fractionation of carbon and nitrogen by marine, planktonic copepods and implications to the marine nitrogen cycle. J Plankton Res 7:553-568

Checkley DM Jr, Miller CA (1989) Nitrogen isotope fractionation by oceanic zooplankton. Deep-Sea Res 36:1449-1456

Cloern JE, Canuel EA, Harris D (2002) Stable carbon and nitrogen isotope composition of aquatic and terrestrial plants of the San Francisco Bay estuarine system. Limnol Oceanogr 47:713-729

DeNiro MJ, Epstein S (1978) Influence of diet on the distribution of carbon isotopes in animals. Geochim Cosmochim Acta 42:495-506

DeNiro MJ, Epstein S (1981) Influence of diet on the distribution of nitrogen isotopes in animals. Geochim Cosmochim Acta 45:341-351

Dittel AI, Epifanio CE, Cifuentes LA, Kirchman DL (1997) Carbon and nitrogen sources for shrimp postlarvae fed natural diets from a tropical mangrove system. Estuar Coast Shelf S 45:629-637

Fantle MS, Dittel AI, Schwalm SM, Epifanio CE, Fogel ML (1999) A food web analysis of the juvenile blue crab, Callinectes sapidus, using stable isotopes in whole animals and individual amino acids. Oecologia 120:416-426

Frazer TK, Ross RM, Quetin LB, Montoya JP (1997) Turnover of carbon and nitrogen during growth of larval krill, Euphausia superba Dana: a stable isotope approach. J Exp Mar Biol Ecol 212:259-275

Fritz P, Poplawski S (1974) ${ }^{18} \mathrm{O}$ and ${ }^{13} \mathrm{C}$ in the shells of freshwater molluscs and their environments. Earth Planet Sc Lett 24:91-98

Fry B, Arnold C (1982) Rapid ${ }^{13} \mathrm{C} /{ }^{12} \mathrm{C}$ turnover during growth of brown shrimp (Panaeus aztecus). Oecologia 54: 200-204

Fry B, Baltz DM, Benfield MC, Fleeger JW, Gace A, Haas HL, Quinones-Rivera ZJ (2003) Stable isotope indicators of movement and residency for brown shrimp (Farfantepenaeus aztecus) in coastal Louisiana marshscapes. Estuaries 26:82-97

Gaston TF, Suthers IM (2004) Spatial variation in $\delta^{13} \mathrm{C}$ and $\delta^{15} \mathrm{~N}$ of liver, muscle and bone in a rocky reef planktivorous fish: the relative contribution of sewage. J Exp Mar Biol Ecol 304:17-33

Gearing JN, Gearing PJ, Rudnick DT, Requejo AG, Hutchins MJ (1984) Isotopic variability of organic carbon in a phytoplankton-based, temperate estuary. Geochim Cosmochim Acta 48:1089-1098

Haines EB, Montague CL (1979) Food sources of estuarine invertebrates analyzed using ${ }^{13} \mathrm{C} /{ }^{12} \mathrm{C}$ ratios. Ecology 60 : 48-56

Hobson KA, Clark RG (1992) Assessing avian diets using stable isotopes. I. Turnover of $\delta^{13} \mathrm{C}$ in tissues. Condor 94 : 181-188

Ishii R, Sekiguchi H, Nakahara Y, Jinnai Y (2001) Larval recruitment of the manila clam Ruditapes philippinarum in Ariake Sound, southern Japan. Fish Sci 67:579-591

Jackson D, Harkness DD (1987) The use and interpretation of $\delta^{13} \mathrm{C}$ values as a means of establishing dietary composition. Oikos 48:258-264 
Jennings $\mathrm{S}$, Reñones $\mathrm{O}$, Morales-Nin $\mathrm{B}$, Polunin NVC, Moranta J, Coll J (1997) Spatial variation in the ${ }^{15} \mathrm{~N}$ and ${ }^{13} \mathrm{C}$ stable isotope composition of plants, invertebrates and fishes on Mediterranean reefs: implications for the study of trophic pathways. Mar Ecol Prog Ser 146: 109-116

Jim S, Ambrose SH, Evershed RP (2004) Stable carbon isotopic evidence for differences in the dietary origin of bone cholesterol, collagen and apatite: implications for their use in palaeodietary reconstruction. Geochim Cosmochim Acta 68:61-72

Keith ML, Anderson GM, Eichler R (1964) Carbon and oxygen isotopic composition of mollusk shells from marine and fresh-water environments. Geochim Cosmochim Acta 28: 1757-1786

Klein Breteler WCM, Grice K, Schouten S, Kloosterhuis HT, Sinninghe Damsté JS (2002) Stable carbon isotope fractionation in the marine copepod Temora longicornis: unexpectedly low $\delta^{13} \mathrm{C}$ value of faecal pellets. Mar Ecol Prog Ser 240:195-204

Macko SA, Lee WY, Parker PL (1982) Nitrogen and carbon isotope fractionation by two species of marine amphipods: laboratory and field studies. J Exp Mar Biol Ecol 63: 145-149

McCutchan JH Jr, Lewis WM Jr, Kendall C, McGrath CC (2003) Variation in trophic shift for stable isotope ratios of carbon, nitrogen, and sulfur. Oikos 102:378-390

Minagawa M, Wada E (1984) Stepwise enrichment of ${ }^{15} \mathrm{~N}$ along food chains: further evidence and the relation between $\delta^{15} \mathrm{~N}$ and animal age. Geochim Cosmochim Acta 48:1135-1140

Oniki H (2003) Production of concentrated pelagic diatoms. AquaNet 6:60-64 (in Japanese)

Owens NJP (1987) Natural variations in ${ }^{15} \mathrm{~N}$ in the marine environment. Adv Mar Biol 24:389-451

Parker PL, Anderson RK, Lawrence A (1989) A $\delta^{13} \mathrm{C}$ and $\delta^{15} \mathrm{~N}$ tracer study of nutrition in aquaculture: Penaeus vannamei in a pond growout system. In: Rundel PW, Ehleringer JR, Nagy KA (eds) Stable isotopes in ecological research. Springer-Verlag, New York, p 288-303

Editorial responsibility: Otto Kinne (Editor-in-Chief), Oldendorf/Luhe, Germany
Peterson BJ, Fry B (1987) Stable isotopes in ecosystem studies. Annu Rev Ecol Syst 18:293-320

Pinnegar JK, Polunin NVC (1999) Differential fractionation of $\delta^{13} \mathrm{C}$ and $\delta^{15} \mathrm{~N}$ among fish tissues: implications for the study of trophic interactions. Funct Ecol 13:225-231

Roer RD, Dillaman RM (1993) Molt-related change in integumental structure and function. In: Horst MN, Freeman JA (eds) Crustacean integument. CRC press, Boca Raton, FL, p 1-37

Schimmelmann A, DeNiro MJ (1986) Stable isotopic studies on chitin. II. The ${ }^{13} \mathrm{C} /{ }^{12} \mathrm{C}$ and ${ }^{15} \mathrm{~N} /{ }^{14} \mathrm{~N}$ ratios in arthropod chitin. Contrib Mar Sci 29:113-130

Schlacher TA, Wooldridge TH (1996) Origin and trophic importance of detritus - evidence from stable isotopes in the benthos of a small, temperate estuary. Oecologia 106: $382-388$

Stephenson RL, Tan FC, Mann KH (1986) Use of stable carbon isotope ratios to compare plant material and potential consumers in a seagrass bed and a kelp bed in Nova Scotia, Canada. Mar Ecol Prog Ser 30:1-7

Tamaki A (2003) A rebuttal to Sakai (2001): 'A review of the common Japanese callianassid species, Callianassa japonica and C. petalura (Decapoda, Thalassinidea)'. Crustaceana 76:115-124

Tamaki A, Ingole B, Ikebe K, Muramatsu K, Taka M, Tanaka M (1997) Life history of the ghost shrimp, Callianassa japonica Ortmann (Decapoda: Thalassinidea), on an intertidal sandflat in western Kyushu, Japan. J Exp Mar Biol Ecol 210:223-250

Tieszen LL, Boutton TW, Tesdahl KG, Slade NA (1983) Fractionation and turnover of stable carbon isotopes in animal tissues: Implications for $\delta^{13} \mathrm{C}$ analysis of diet. Oecologia 57: 32-37

Vander Zanden MJ, Rasmussen JB (2001) Variation in $\delta^{15} \mathrm{~N}$ and $\delta^{13} \mathrm{C}$ trophic fractionation: implications for aquatic food web studies. Limnol Oceanogr 46:2061-2066

Wada E, Terazaki M, Kabaya Y, Nemoto T (1987) ${ }^{15} \mathrm{~N}$ and ${ }^{13} \mathrm{C}$ abundances in the Antarctic Ocean with emphasis on the biogeochemical structure of the food web. Deep-Sea Res $34: 829-841$

Submitted: September 28, 2004; Accepted: January 27, 2004 Proofs received from author(s): June 27, 2005 